\title{
Biodiversity, Distribution and coverage of seagrasses in the Myeik Archipelago and Rakhine Coastal Areas, in Myanmar
}

\begin{abstract}
Seagrasses provide ecological services to marine organisms that contribute towards food security and economic benifits to local communities living around their meadows. Surveys on seagrass taxonomy, distribution and extent were carried out in Myanmar in 14 sites within the Myeik Archipelago and along the Rakhine coast to assess the status of these important habitats. This study follows the guidelines of taxonomic monographs and the SeagrassNet manual to survey species diversity, percent cover and extent. A total of 11 species of seagrasses were recorded, including Syringodium isoetifolium, Cymodocea rotundata, C. serrulata, Halodule uninervis, H. pinifolia, Enhalus acoroides, Thalassia hemprichii, Halophila beccarii, H. decipiens, $H$. ovalis and H. major. Of these, Halophila pinifoliawas the most commonly observed species and the only one to be distributed across all 14 study sites. In contrast, Halophila beccarii was only recorded at Ma Gyi along the Rakhine coast. Other uniquie species distributions include Halophila major which was solely found along the Rakhine coast and $H$. ovalis which was exclusively encountered along the Myeik Archipelago. The habitat types of seagrasses between the two Coastal Regions were also found to be differred with seagrass meadows in Taninthayi most commonly observed in coastal intertidal habitat whereas those in Rakhine were recorded in the fringing reef and deep subtidal habitat. In terms of species diversity among the 14 study sites, Ma Gyi Gyaing and Pho Htaung Gyaing showed the highest in Rakhine with 9 species each while Zar Det Ngye I (East) and Pa Law Kar Kyan I in Taninthayi contained 7 species each. Highest percentage cover of seagrass meadows was observed at Maung Shwe Lay Gyaing, in Rakhine with $67.00 \%$ and the highest coverage in Taninthayi at Lampi I (East) with $64.57 \%$. Given the environmental services provided by seagrasses their protection within Myanmar is critical. All areas should be granted a certain level of protection although priotiry firstly needs to be given to Ma Gyi Gyaing in Rakhine given its species diversity, being the only site to conatin the Vulnerable listed Halophila beccarii species and beacsue of its high percent cover. Such an area should be gazzetted as a Marine Protected Area (MPA) along with Pa Law Kar Kyan I., Zar Det Ngye I. (East) and Lampi I. (East) in the Taninthayi Coastal Region and Ma Gyi Gyaing, Pho Htaung Gyaing and Maung Shwe Lay Gyaing in the Rakhine Coastal Region given their species diversity and extent.
\end{abstract}

Keywords: Biodiversity, Conservation, Ecological accounts, Morphology, Local distribution, Myanmar, Percent cover, Rakhine Coastal Region, Taninthayi Coastal Region, Seagrasses taxonomy
Volume 6 Issue 4 - 2017

\author{
U Soe-Htun,' Antt Maung, ${ }^{2}$ Salai Mon, ${ }^{2}$ Soe \\ Thi Ha, ${ }^{2}$ Soe Tint Aung, ${ }^{2}$ Aung Myo Lwin, ${ }^{2} \mathrm{U}$ \\ Zau Lunn ${ }^{3}$ \\ 'Director, Marine Science Association (MSAM), Myanmar \\ ${ }^{2}$ Marine biologist and Research Diver in Marine Conservation \\ Programme in Fauna \& Flora International (FFI), Myanmar \\ ${ }^{3}$ Director, Fauna \& Flora International (FFI), Myanmar
}

Correspondence: U. Soe-Htun, Director, Marine Science
Association, Myanmar (MSAM), Yangon, Myanmar, Email usoehtun@gmail.com

Received: April 24, 2017| Published: November 01, 2017

\section{Introduction}

Seagrasses are a relatively small group of submerged flowering plants of approximately 72 species, representing less than $0.1 \%$ of the angiosperm taxa growing in shallow coasts of the tropical and subtropical regions. However, about $60 \%$ of seagrass meadows globally have been seen reductions in their distribution since $1980 .^{1,2}$ The ecological importance of seagrass beds has been well documented and includes the provision of sheltered habitats and crucial feeding, spawning and nursery grounds for economically important species of marine invertebrates and fish species. ${ }^{3-7}$ Furthermore they are key primary producers, involved in epibenthic and benthic production; provide important nutrients and contaminant filtration, producers of oxygen, recycles of nutrients. ${ }^{8}$ However, since 1980 about $60 \%$ of seagrass populations globally have seen a reduction in their distribution due to habitat destruction and marine pollution. ${ }^{1,2}$

Seagrasses occur all along three Coastal Regions of Myanmar, namely Rakhine, Ayeyarwady Delta and the Gulf of Mottama (Martaban) and Taninthayi. Ten species of seagrasses has been described in Myanmar and include, viz., Syringodium isoetifolium (Ascherson) Danty, Cymodocea serrulata (R. Brown) Ascherson et Magnus, C. rotundata Ehrenberg et Hemprich ex Ascherson, Halodule uninervis (Forsskal) Ascherson, $H$. pinifolia (Miki) Den Hartog, ${ }^{9}$ Enhalus acoroides (Linnaeus f.) Royle, Thalassia hemprichii (Ehrenberg) Ascherson, Halophila beccarii Ascherson, H. decipiens Ostenfeld and H. ovalis (R. Brown) Hooker f. ${ }^{10-15}$ Their importance to Myanmar fishers is well known with local people calling seagrasses Leik-Sar-Phat-Myet, meaning the food of marine turtles. In addition, the seagrass meadows are known to serve as important feeding grounds for the sea cow, Dugong dugon which is recognized as endangered species under the IUCN Red list. Given their importance, both ecologically and economically, and the global decline in segarss beds, the protection of seagrasses within Myanmar is seen as paramount. The objective of this study was to know the updated information on the current status of biodiversity, distribution and coverage of seagrasses at select sites within the Taninthayi and the Rakhine Coastal Regions of Myanmar. This information will be used to guide the creation of Marine Protected Areas within Myanmar to ensure such habitats are conserved and used for long term monitoring of seagrasses. 


\section{Materials and methods}

Ten study sites were selected in the Myeik Archipelago along the Taninthayi coast (Figures $1 \& 2$ ) and four study sites in Rakhine (Figures $1 \& 3$ ) to gain an understanding of their status and suitability for MPA designation. Surveys were conducted in 2015 between the 6th of March to 4th of April in Tanintanryi and 1st to the 31 May and included the following sites:

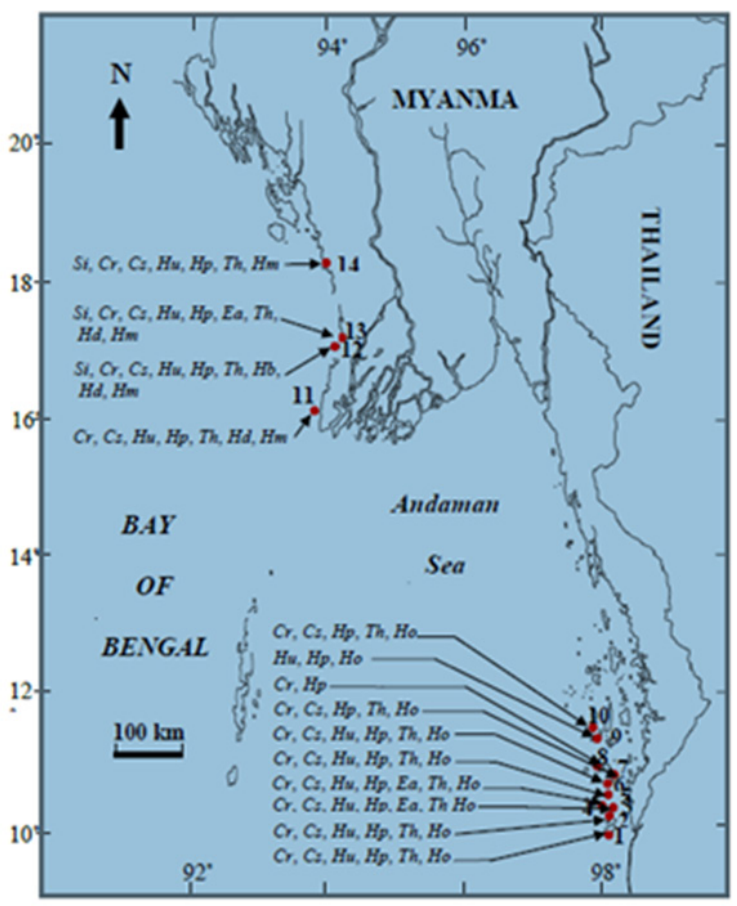

Figure I Map showing I 4 study sites with the biodiversity and distribution of seagrasses growing in the Taninthayi and Rakhine Coastal Regions: I. Zar Det Gyi; 2. Zar Det Ngye (West); 3. Zar Det Ngye (East); 4. Pa Law Kar Kyan I. (St Luke I.); 5. Nyaung Wee I.; 6. Bo Cho I.; 7. Lampi I. (East); 8. Lampi I. (West); 9. Taw Wet I. (South); I O. Taw Wet I. (North); I I. Ohn Kyun I.; I 2. Ma Gyi Gyaing (Shwe Thaung Yan); 13. Pho Htaung Gyaing; and 14. Maung Shwe Lay Gyaing.

Abbreviations: $\mathrm{Si}$, Syringodium isoetifolium; $\mathrm{Cr}$, Cymodocea rotundata; $\mathrm{Cs}, \mathrm{C}$. serrulata; $\mathrm{Hu}$, Halodule uninervis; $\mathrm{Hp}, \mathrm{H}$. pinifolia; Ea, Enhalus acoroides; Th, Thalassio hemprichii; $\mathrm{Hb}$, Halophila beccarii; $\mathrm{Hd}, \mathrm{H}$. decipiens; $\mathrm{Ho}, \mathrm{H}$. ovalis and $\mathrm{Hm}, \mathrm{H}$. major.

\section{Taninthayi coastal region:}

\section{Zar Det Gyi I.}

Seagrass bed was located in front of the mangrove communities at Lat $10.02003^{\circ}$, Long $98.28963^{\circ}$. Substrates are muddy sand and sandy mud to offshore. The area of seagrass bed was $32.80 \mathrm{ac}$. The percent cover of seagrasses along the cross-transects was estimated on March 23, 2015.

\section{Zar Det Ngye I. (West)}

Seagrass bed was located in front of the mangrove communities at Lat $10.11687^{\circ}$, Long $98.28199^{\circ}$. Substrates are muddy sand near shore becoming sand to offshore. The area of seagrass bed was 12.10 ac. The percent cover of seagrasses along the cross-transects was estimated on March 22, 2015.

\section{Zar Det Ngye I. (East)}

Seagrass bed was located in front of the mangrove communities at Lat $10.1251^{\circ}$, Long $98.3045^{\circ}$. Substrates are muddy sand inshore and sandy mud at offshore. The area of seagrass bed was 19.90 ac. The percent cover of seagrasses along the cross-transects was estimated on March 24, 2015.

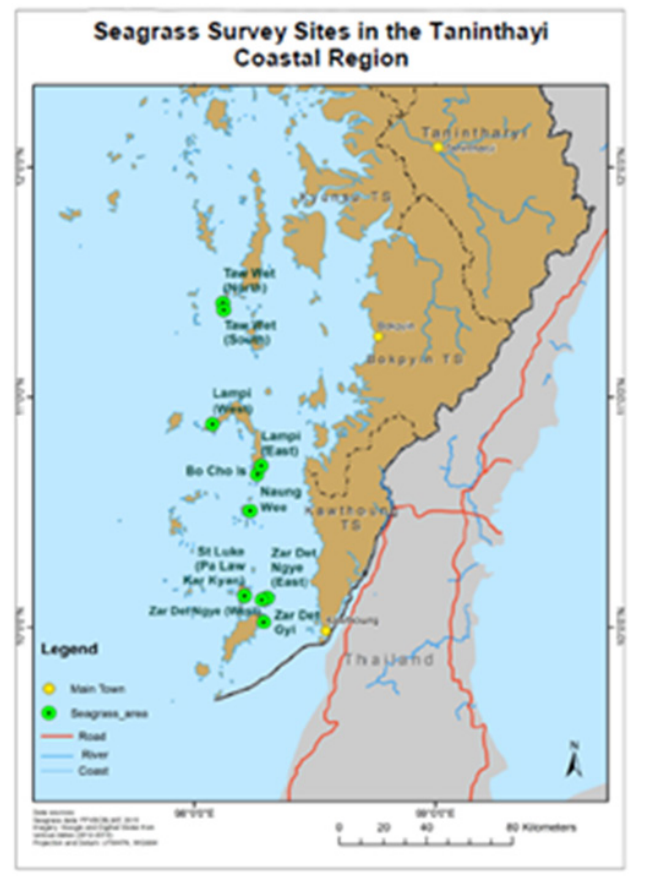

Figure 2 The survey sites of seagrass areas in the Myeik Archipelago, in the Taninthayi Coastal Region.

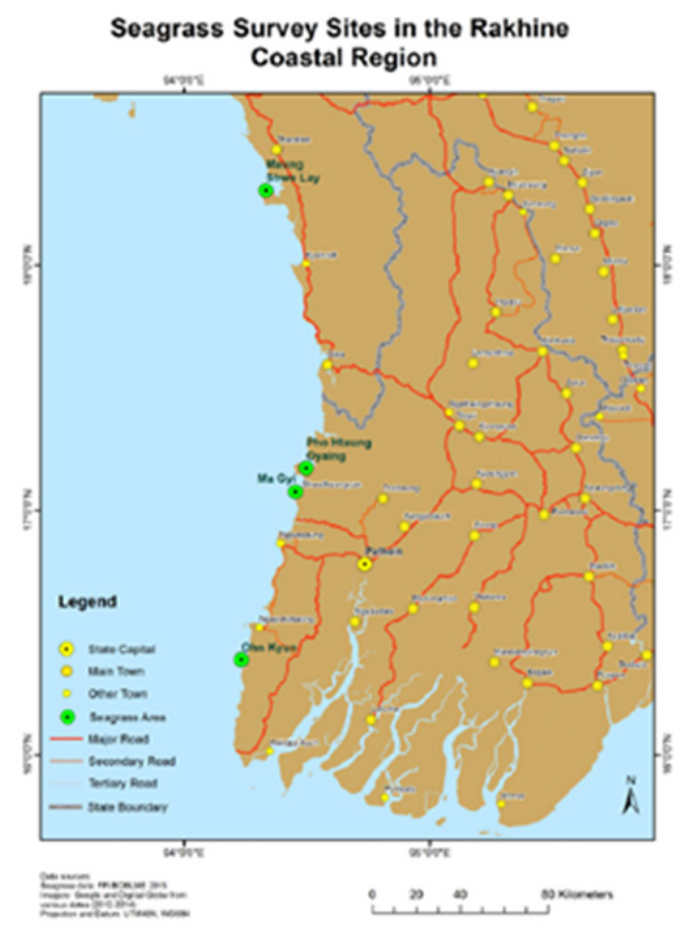

Figure 3 The survey sites of seagrass areas in the Rakhine coastal region.

\section{Pa Law Kar Kyan (St. Luke)}

Located in front of the mangrove communities at Lat $10.13461^{\circ}$, Long $98.21011^{\circ}$. Substrates are muddy sand nearshore and sandy mud 
to offshore. The area of seagrass bed was $83.00 \mathrm{ac}$. The percent cover of seagrasses along the cross-transects was estimated on March 21, 2015.

\section{Nyaung Wee I.}

Seagrass bed was located in front of the mangrove communities at Lat $10.50319^{\circ}$, Long $98.23227^{\circ}$. Substrates are muddy sand in nearshore, becoming sandy mud to offshore. The area of seagrass bed was $46.40 \mathrm{ac}$. The percent cover of seagrasses along the crosstransects was estimated on March 20, 2015.

\section{Bo Cho I.}

Located in front of the sandy beach without mangrove communities at Lat $10.66216^{\circ}$, Long $98.26^{\circ}$. Water depth $5 \mathrm{~m}$. Substrates are muddy sand in nearshore and sandy mud to offshore. The area of seagrass bed was $382.50 \mathrm{ac}$. The percent cover of seagrasses along the crosstransects was estimated on March 18, 2015.

\section{Lampi I. (East)}

Seagrass bed was located in front of the sandy beach without mangrove communities at Lat $10.70202^{\circ}$, Long $98.27984^{\circ}$. Substrates are muddy sand and sandy mud to offshore. The area of seagrass bed was $216.70 \mathrm{ac}$. The percent cover of seagrasses along the crosstransects was estimated on March 19, 2015.

\section{Lampi I. (West)}

Seagrass bed was located in front of the sandy beach without mangrove communities at Lat $10.88089^{\circ}$, Long $98.07436^{\circ}$. Substrates are muddy sand nearshore and sandy mud to offshore. The area of seagrass bed was $10.60 \mathrm{ac}$. The percent cover of seagrasses along the cross-transects was estimated on March 16, 2015.

\section{Taw Wet I. (South)}

Seagrass bed was located in front of the mangrove communities at Lat $11.37642^{\circ}$, Long $98.12234^{\circ}$. Substrates are muddy sand becoming sandy mud to offshore. The area of seagrass bed was $28.90 \mathrm{ac}$. The percent cover of seagrasses along the cross-transects was estimated on March 11, 2015.

\section{Taw Wet I. (North)}

Seagrass bed was located in front of the mangrove communities at Lat $11.40776^{\circ}$, Long $98.12032^{\circ}$. Substrates are predominantly muddy sand and becoming sandy mud to offshore. The area of seagrass bed was 45.50 ac. The percent cover of seagrasses along the crosstransects was estimated on March 11, 2015.

\section{Rakhine Coastal Region:}

\section{Ohn Kyun I.}

Seagrass bed was located in front of the sandy beach without mangrove communities at Lat $16.388765^{\circ}$, Long $94.229125^{\circ}$. Substrates are muddy sand in nearshore and sandy mud to offshore. The area of seagrass bed was $17.30 \mathrm{ac}$. The percent cover of seagrasses along the cross-transects was estimated on May 8, 2015.

\section{Ma Gyi Gyaing}

Seagrass bed was located in front of the sandy beach without mangrove communities at Lat $17.072122^{\circ}$, Long $94.451406^{\circ}$. Substrates are muddy sand nearshore and sandy mud to offshore. The area of seagrass bed was 39.83 ac. The percent cover of seagrasses along the cross-transects was estimated on May 1, 2015.

\section{Pho Htaung Gyaing}

Seagrass bed was located in front of the mangrove communities at Lat $17.170547^{\circ}$, Long $94.491739^{\circ}$. Substrates are muddy sand in nearshore and sandy mud to offshore. The area of seagrass bed was 94.22 ac. The percent cover of seagrasses along the cross-transects was estimated on May 2, 2015.

\section{Maung Shwe Lay Gyaing}

Seagrass bed was located in front of the sandy beach without mangrove communities at Lat $18.305367^{\circ}$, Long $94.329312^{\circ}$. Substrates are muddy sand in nearshore and sandy mud in offshore. The area of seagrass bed was $23.79 \mathrm{ac}$. The percent cover of seagrasses along the cross-transects was estimated on May 15, 2015.

Fresh and live materials of seagrasses growing in the natural beds of 14 study sites were sampled by uprooting the seagrasses with a small trowel or knife from 6-3-2015 to 31-5-2015. Snorkeling or scuba equipment was used for the submersed habitats of seagrasses growing in subtidal zone of the Rakhine coast indepths between 2-5m, while surveys were conducted during the ebb tide in the Myeik Archipelago. The collections were initially washed, cleaned and preserved in $10 \%$ formalin in seawater. Samples of seagrasses were examined mainly on the vegetative characters with a dissecting microscope, and then pressed on herbarium sheets to prepare as voucher specimens for each locality. As for taxonomic account, all specimens were identified using the standard monograph of seagrasses prepared by den Hartog $\&$ Kuo et al. ${ }^{9}{ }^{16}$ This study had followed the classification system used by Fortes. ${ }^{17}$ All voucher specimens were deposited at the Herbarium of Department of Marine Science, Mawlamyine University (MMB), Mawlamyine, Myanmar.

In relation to the ecological accounts, this study has followed the SeagrassNet protocol by Short et al., ${ }^{18,19}$ consisting of three fixed, parallel, $50 \mathrm{~m}$ cross-transects referred to as cross-transects A, B and $\mathrm{C}$, with cross-transect $\mathrm{A}$ closest to shore and $\mathrm{C}$ most seaward; $\mathrm{B}$, midpoint of these cross-transects were established on a transect laid out seaward, perpendicular to the shore. Percentage cover of seagrasses was visually estimated within 12 randomly placed $0.25 \mathrm{~m} 2$ quadrats along each cross-transect using a photo guide of percent cover. As noted above these works were done intetidally in the coastal areas of the Myeik Archipelago (Figure 4A) but subtidally in the Rakhine coastal areas using snorkling or scuba equipment (Figure 4B). Positions and areas of seagrasss for each study site were recorded by GPS with extent being recorded by walking around the seagrass bed taking GPS points every 10 secs. The physical parameters, namely temperature using a mercurial thermometer, salinity using a refectometer, water depths using handheld sounder were measured in the field. The types of substrate were also recorded.

\section{Results}

In the present study, a total of 11 species of seagrasses were identified: including Syringodium isoetifolium (Ascherson) Danty, Cymodocea rotundata Ehrenberg etHemprichexAscherson, C. serrulata(R.Brown) Ascherson et Magnus, Halodule uninervis (Forsskal) Ascherson, $H$. pinifolia (Miki) den Hartog, Enhalus acoroides (Linnaeus f.) Royle, Thalassia hemprichii (Ehrenberg) Ascherson, Halophila beccarii Ascherson, H. decipiens Ostenfeld; 10. H. ovalis (R. Brown) Hooker f. and H. major (Zoll.) Miquel (Table 1). A detailed account of the taxonomy of these plants including identification guide, ecological accounts and supplementary survey data were shown in Appendices $1-8$ of this report. Of these species, only one, Halophila beccarii is 
considered Vulnerable according to the IUCN RedList, with all othe species listed as Least Concern.
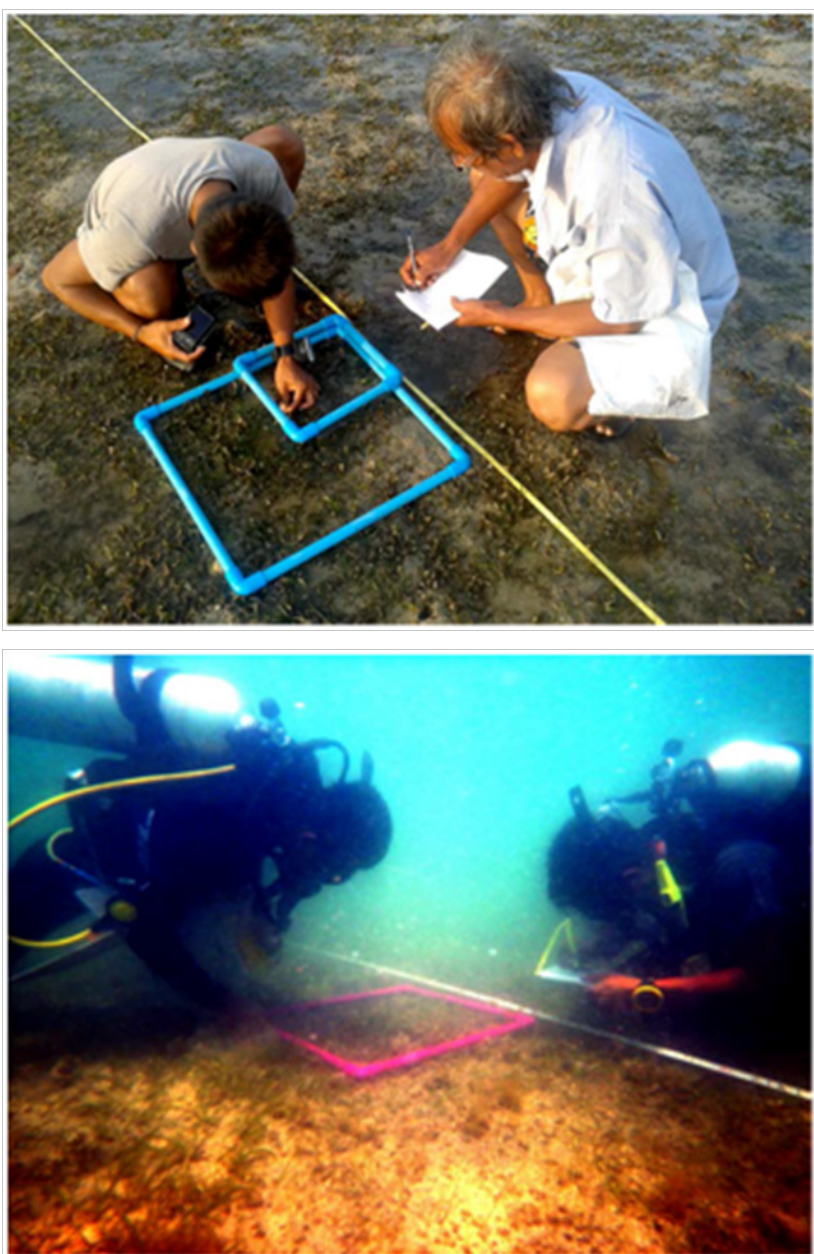

Figure 4 A-B A: Recording the percentage cover of seagrasses growing in intertidal zone in the coastal areas of the Myeik Archipelago of the Taninthayi. $B$ : Investigating the percentage cover of seagrasses growing in subidal zone in the coastal areas of Rakhine.

\section{Syringodium isoetifolium(AschersonDanty (Figure 5)}

a. Description: Plants erect; the rhizome $1 \mathrm{~mm}$ thick, with internodes, 1.4-2.5 cm long; each node giving a shoot with 1-3 leaves; leaves terete, tapering to the tip, $5.5-12.5 \mathrm{~cm}$ in length (or longer), $1 \mathrm{~mm}$ wide, base covered by leaf sheath, $1-3 \mathrm{~cm}$ long.

b. Local distribution: (1) The Taninthayi Coastal Region- No data; (2) The Rakhine Coastal Region- Ma Gyi, Pho Htaung Gyaing, Maung Shwe Lay Gyaing (Figures 1,3).

\section{Cymodocea rotundataEhrenberg et Hemprich ex} Ascherson (Figures 6-7)

a. Description: Erect plants moderate in size; the rhizome cylinder, internodes 1.5-6.0 cm long; one root per node; rhizome creeping, less than $1 \mathrm{~mm}$ in diameter; erect shoots with 2-4 leaves, borne at the nodes with lingual or densely aggregated and formed cymosely; leaf blades, linear, falcate, $1.5-9.5 \mathrm{~cm}$ long, 1.5- 2.0 $\mathrm{mm}$ wide, petioles- $0.1-1.1 \mathrm{~cm}$ long with lingula, leaf-tip obtuse, leaf margin entire with 8-10 nerves, leaf sheath $1.3-1.7 \mathrm{~cm}$ long; deciduous form very common; remnants of many scars of liberated shoot distinct, old shoots usually deciduous from main stem. b. Local distribution: (1) The Taninthayi Coastal Region- Zar Det Gyi I., Zar Det Ngye I. (West \& East), Pa Law Kar Kyan I. (St. Luke Island), Nyaung Wee I., Bo Cho I., Lampi I. (East \& West), Taw Wet I. (North)(Figures 1,2); (2) The Rakhine Coastal Region- Ohn Kyun, Ma Gyi, Pho Htaung Gyaing, Maung Shwe Lay Gyaing (Figures 1,3).
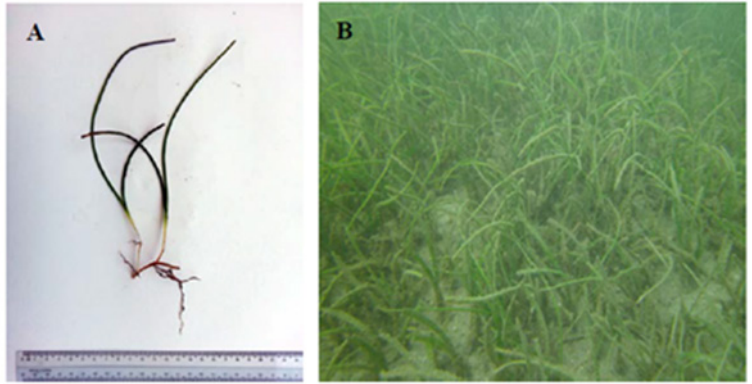

Figure 5 Syringodium isoetifolium:A. Habit, and B.The natural bed.
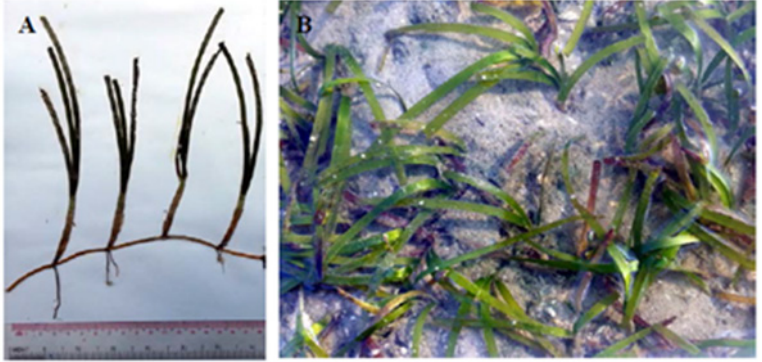

Figure 6 Cymodocea rotundata:A. Habit, and B. The natural bed.
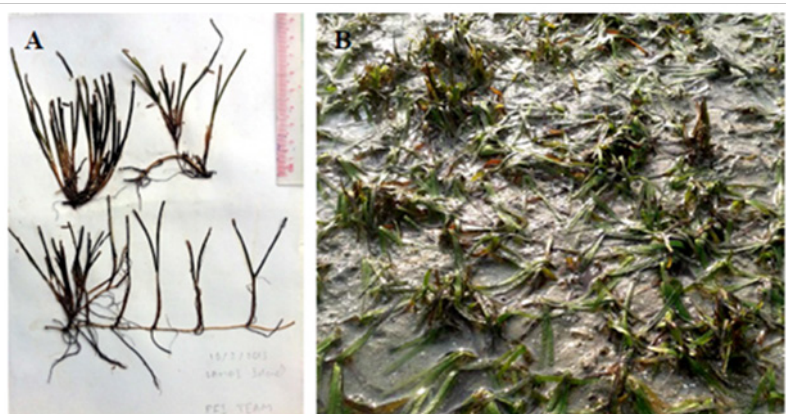

Figure 7 Deciduous form of Cymodocea rotundata:A. Habit, and B.The natural bed.

\section{Cymodocea serrulata(R. Brown) Ascherson et Magnus (Fig. 8)}

a. Description: Erect plants moderate in size; the rhizome $1 \mathrm{~mm}$ in diameter, slightly larger than $C$. rotundata, internodes $2.2-3.3 \mathrm{~cm}$ long; shoots with 2-3 leaves at each node with lingula; leaf blade linear, flat, 4-13 cm long, 4.5-5.5 mm wide, margin entire with 9-15 nerves, apex serrulate, tapering at the base, leaf sheaths 1.5 $3.0 \mathrm{~cm}$ long

b. Local distribution: (1) The Taninthayi Coastal Region- Zar Det Gyi I., Zar Det Ngye I. (West \& East), Pa Law Kar Kyan I., Nyaung Wee I., Bo Cho I., Lampi I. (East); Taw Wet (North) (Figures 1, 2); (2) The Rakhine Coastal Region- Ohn Kyun I., Shwe Thaung Yan (Ma Gyi), Pho Htaung Gyaing, Maung Shwe Lay Gyaing (Figures 1, 3). 


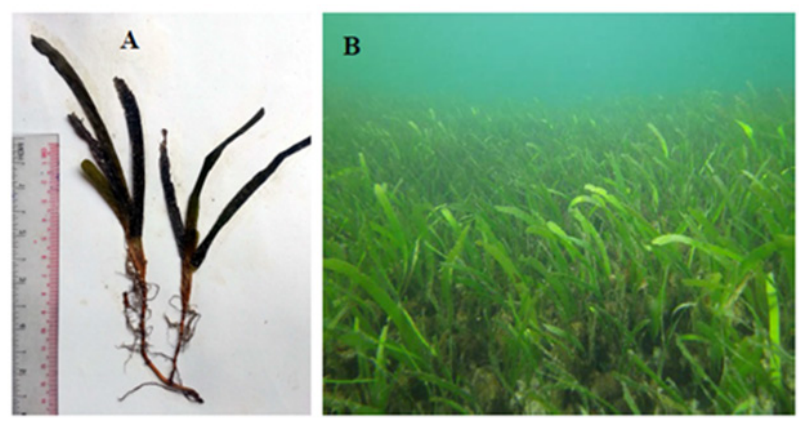

Figure 8 Cymodocea serrulata:A. Habit, and B.The natural bed.

\section{Halodule uninervis(Forsskal) Ascherson (Figure 9)}

a. Description: Rhizome not exceeding than $1 \mathrm{~mm}$ thick; the internodes 1.8-3.5 cm long; erect shoot arising 1-3 flat, linear blades at each node with lingula; leaf blades flat, $13-25 \mathrm{~cm}$ long, 1-2 mm wide, margin entire, the black central vein at the leaf tip, which does not splits into two at the apex, leaf sheath present, $1.5-3.0 \mathrm{~cm}$ long.

b. Local distribution: (1) The Taninthayi Coastal Region- Zar Det Gyi I., Zar Det Ngye I. (West \& East), Pa Law Kar Kyan I., Nyaung Wee I., Bo Cho I., Lampi I. (East)(Figures 1,2); Taw Wet (North); (2) The Rakhine Coastal Region- Ohn Kyun I., Shwe Thaung Yan (Ma Gyi), Pho Htaung Gyaing, Maung Shwe Lay Gyaing (Figures 1,3).
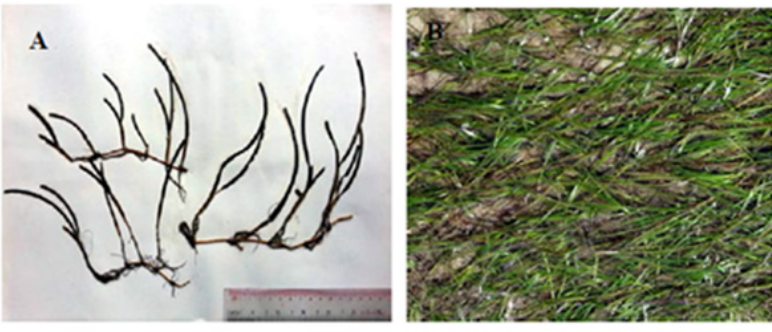

Figure 9 Halodule uninervis: A. Habit, and B. The natural bed.

\section{Halodule pinifolia(Miki) den Hartog (Fig. I0)}

a. Description: Plants small; the rhizome less than $1 \mathrm{~mm}$, with internodes, $1.5-5.4 \mathrm{~cm}$ long; nodes bear erect shoots, each with 2-3 leaves; leaf blades flat, $4-25 \mathrm{~cm}$ long, not more than $1 \mathrm{~mm}$ wide, the black central vein at the leaf tip, which splits into two at the apex, lingua present at each node.

b. Local distribution: (1) The Taninthayi Coastal Region- Zar Det Gyi I., Zar Det Ngye I. (West \& East), Pa Law Kar Kyan I. (St. Luke I.), Nyaung Wee I., Bo Cho I., Lampi I. (East \& West), Taw Wet I. (South \& North)(Figures 1,2); (2) The Rakhine Coastal Region- Ohn Kyun I., Ma Gyi, Pho Htaung Gyaing, Maung Shwe Lay Gyaing (Figures 1,3).

\section{Enhalus acoroides(Linnaeus f.) Royle (Figure II)}

a. Description: Plant erect; the rhizome thick, about $1-2 \mathrm{~cm}$ in diameter with tough black fibers; shoots pronounced at the node, with 3-6 leaves; leaf blades flat and linear, 70-180 cm long, 0.8$2.0 \mathrm{~cm}$ wide, with $35-55$ nerves and ribs at the margin, apex obtuse, base narrow without lingula, margin slightly serrulate in young leaves. b. Local distribution: (1) The Taninthayi Coastal Region- Zar Det Ngye I. (East), St. Luke I. (Figures 1,2); (2) The Rakhine Coastal Region- Pho Htaung Gyaing (Figures 1,3).
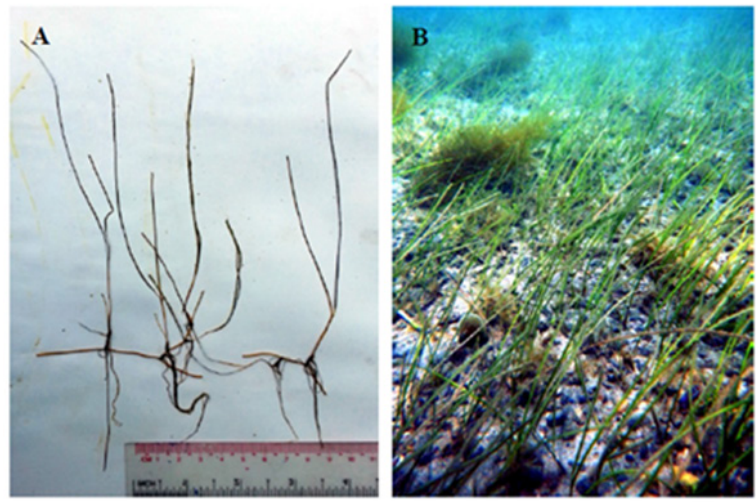

Figure 10 Halodule pinifolia:A. Habit, and B. The natural bed.
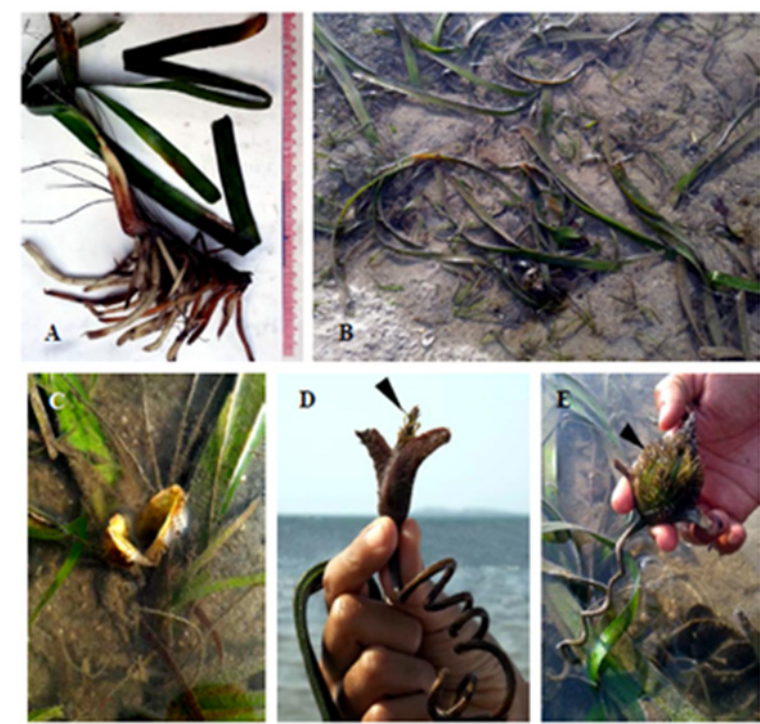

Figure II Enhalus acoroides: A. Habit, B. The natural bed, C. Male flower (arrowhead), D. Female flower (arrowhead) and E. Fruit (arrowhead).

\section{Thalassia hemprichii(Ehrenberg) Ascherson (Figure 12)}

a. Description: Plants moderate in size; intervals of internode1.9-9.0 cm long; one root per node; rhizome creeping, less than $1 \mathrm{~mm}$ in diameter, distichously arranged and formed dendroid in shape; leaf blade linear, falcate, 1.5-15.0 cm long, 1.5- $2.0 \mathrm{~mm}$ wide, petioles- $0.1-1.1 \mathrm{~cm}$ long without lingula, leaf-tip obtuse, sometimes serrulate, nerves $8-11$, joined by perpendicular cross veins with 9-13 nerve. Leaf tip rounded with very fine serrulations. A common species characterized by a thick rhizome prominently marked by several shoot scars between successive erect shoots with numerous relatively short internodes and a short erect stem bearing 2-6 leaves.

b. Local distribution.- (1) The Taninthayi Coastal Region- Zar Det Gyi I., Zar Det Ngye I., St. Luke I., Naung Wee I., Bo Cho I., Lampi I. (East), Taw Wet (North)(Figs. 1, 2); (2) TheRakhine Coastal Region- Ohn Kyun I., Shwe Thaung Yan (Ma Gyi), Pho Htaung Gyaing, Maung Shwe Lay Gyaing (Figures 1,3). 


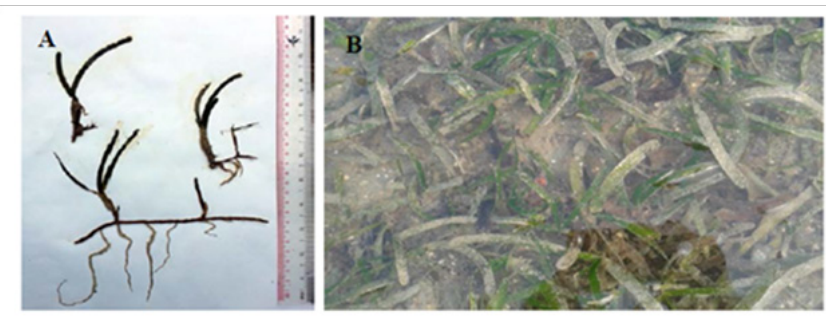

Figure 12 Thalasia hemprichii:A. Habit, and B. The natural bed.

\section{Halophila beccarii Ascherson(Figure I3)}

a. Description: Plants small; the rhizome less than $1 \mathrm{~mm}$ in diameter with internodes 1.1-1.6 cm long; each node bears petiolated leaves; leaf blades linear to lanceolate, $5.5-7.5 \mathrm{~mm}$ long, 1.5 $2.0 \mathrm{~mm}$ wide, petiole $8-14 \mathrm{~mm}$ long, apex acute, base attenuate, margin entire, with 1-3 paralleled veins and no cross-veins.

b. Local distribution: (1) The Taninthayi Coastal Region- No data; (2) The Rakhine Coastal Region- Magyi (Figures 1,3).

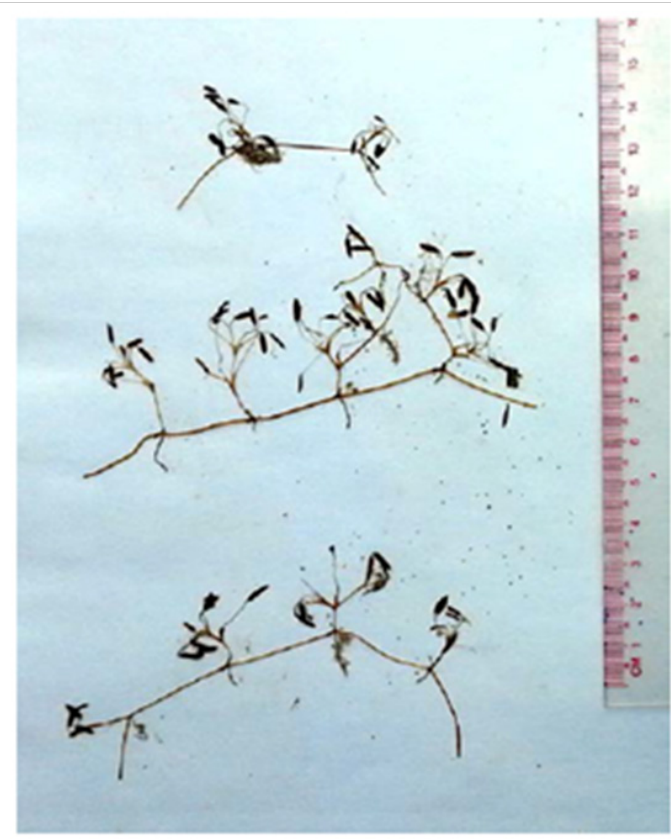

Figure I 3 Halophila beccarii: Habit.

\section{Halophila decipiens Ostenfeld (Figure I4)}

a. Description: Plants small; the rhizomes less than $1 \mathrm{~mm}$ in diameter; internodes 1.2-2.7 cm long; leaf blades lanceolate to oblong, 1.0-1.7 cm long, 3-6 mm wide; margin finely serrated, with conspicuous midrib and persistent cross-veins, apex obtuse, petiole $1.0-1.7 \mathrm{~cm}$ long, base unclosed by a pair of transparent scale.

b. Local distribution: (1) The Taninthayi Coastal Region- No data; (2) The Rakhine Coastal Region- Ohn Kyun I., Magyi, Pho Htaung Gyaing (Figures 1,3).

\section{Halophila ovalis(R. Brown) Hooker f. (Figures I,3)}

a. Description: Plants small; the rhizome less than $1 \mathrm{~mm}$ in diameter, slightly larger than $H$. decipiens, internodes $1.8-2.4 \mathrm{~cm}$ long; erect shoot at each node, bearing a pair of petiolated leaves; leaf blades lanceolate to obovate or elliptic, $1.5-2.2 \mathrm{~cm}$ long, 7-10 mm wide, margin entire, apex obtuse, base rounded, petiole 2.2-3.0 $\mathrm{cm}$ long, midrib prominent with $14-17$ cross-veins, the distance between the intra-marginal vein and the lamina margin ratio $1: 12$ to $1: 16$.

b. Local distribution: (1) The Taninthayi Coastal Region- Zar Det Gyi I, Zar Det Ngye I (West \& East), Pa Law Kar Kyan I ( St. Luke I), Nyaung Wee I, Bo Cho I, Lampi I (East), Taw Wet I (South \& North)(Figures 1 \& 2); (2) The Rakhine Coastal Region- No data.
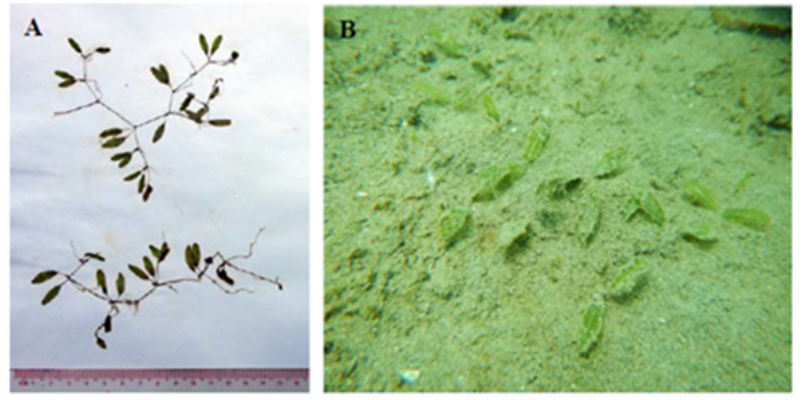

Figure I 4 Halophila decipiens:A. Habit, and B. The natural bed.

\section{Halophila major (Zoll.) Miquel (Figure I6)}

a. Description: Plants moderate in size; slightly larger than $H$. ovalis, perennial; rhizomes slender to robust, fleshy, transparent, internodes $25-40 \mathrm{~mm}$ long, $1-2 \mathrm{~mm}$ diameter; roots up to 50 $\mathrm{mm}$ long, $1.5 \mathrm{~mm}$ diameter. Scales 2, glabrous, margins entire, petiole scale $3-5 \times 1-2 \mathrm{~mm}$, rhizome scale $4-55 \times 1.0-2.5 \mathrm{~mm}$; leaves petiolate, fleshy, purple to light green, $15-30 \mathrm{~mm}$ long, leaves bright to dark green, ovate, oblong to elliptic, $15-25 \mathrm{~mm}$ long, 9-11 mm wide, L:W ratio 1-3:1; apex acute or acuminate; base cuneate to attenuate, symmetrical: margins entire; surface glabrous; distance between intramarginal veins and lamina margin ratio 1:20.8-25.6; cross-veins distinct,18-20, distance between adjacent cross veins $0.7-1.25 \mathrm{~mm}$ wide.

b. Local distribution: (1) The Taninthayi Coastal Region- No data; (2) The Rakhine Coastal Region- Ohn Kyun I., Ma Gyi, Pho Htaung Gyaing, Maung Shwe Lay Gyaing (Figure 1 \& 3).
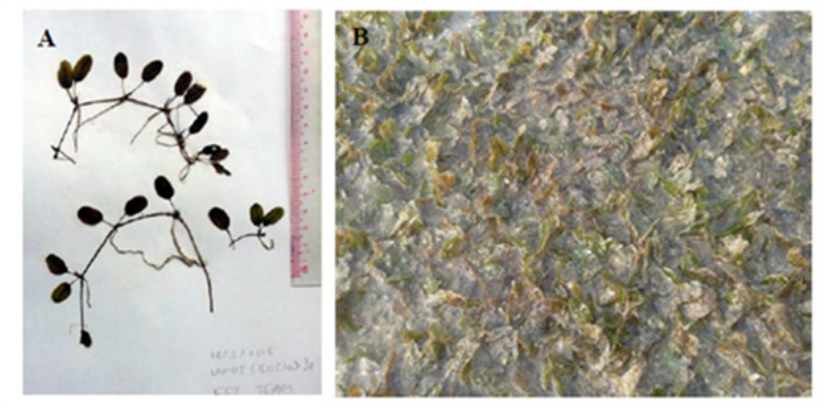

Figure I 5 Halophila ovalis:A. Habit, and B. The natural bed.

In this study, Halophila pinifolia was the most commonly observed species and the only one to be distributed across all 14 study sites (Table 1). In contrast, Halophila beccarii was only recorded at Ma Gyi Gyaing along the Rakhine coast. Other uniquie species distributions include Halophila major which was found along the Rakhine coast and $H$. ovalis was encountered only along the Tanintharyi coast. The most frequently observed species along the transects was Cymodocea rotundata and H. ovalis while the least was Thalassia hemprichii. Enhalus acoroides and Halophila beccarii were not 
recorded along the transects and only opportuniscally observed during the survey and considered low in abundance.
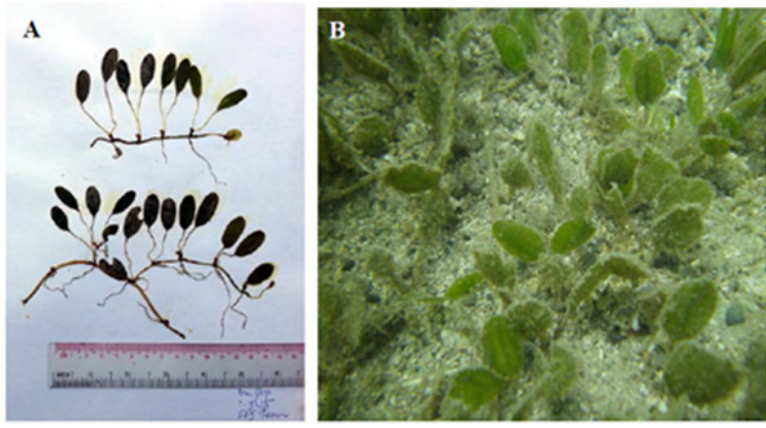

Figure 16 Halophila major:A. Habit, and B. The natural bed.

Table I Biodiversity of seagrasses distributed in 14 study sites in the Taninthayi and Rakhine Coastal Regions of Myanmar

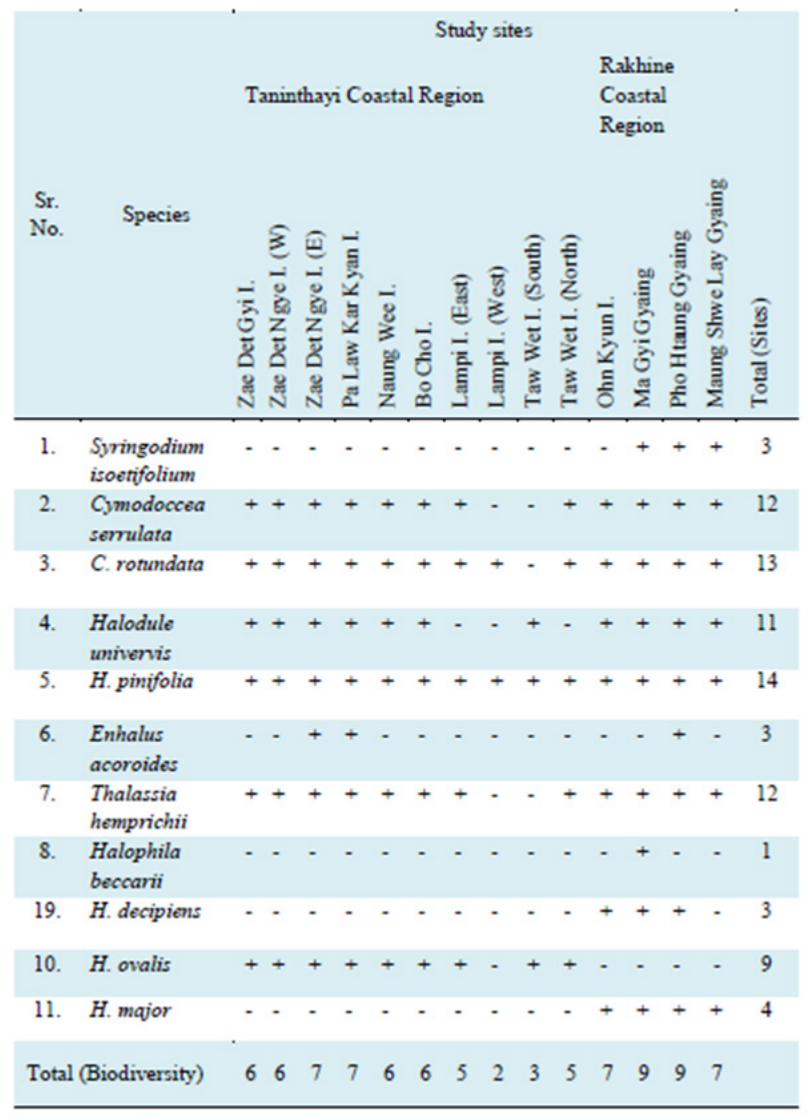

Symbols: $+=$ Present, $-=$ Absent .

The tidal habit of seagrasses between the two Coastal Regions was also found to differ with seagrass meadows in Taninthayi most commonly observed in intertidal zones whereas those in Rakhine were recorded in the subtidal zone (Table 3 ). In terms of species diversity among the 14 study sites, Ma Gyi Gyaing and Pho Htaung Gyaing showed the highest in Rakhine with 9 species each while in Taninthayi Zar Det Ngye I. (East) and Pa Law Kar Kyan I. contained 7 species each. Highest percentage cover of seagrass meadows was observed at Maung Shwe Lay Gyaing, in Rakhine with $67.36 \%$ and the highest coverage in Taninthayi at Lampi I. (East) with $64.57 \%$ (Table 2) (Figures 17-18). Although no statistical tests were undertaken no clear pattern was observed in terms of species diversity or density from inshore to offshore.

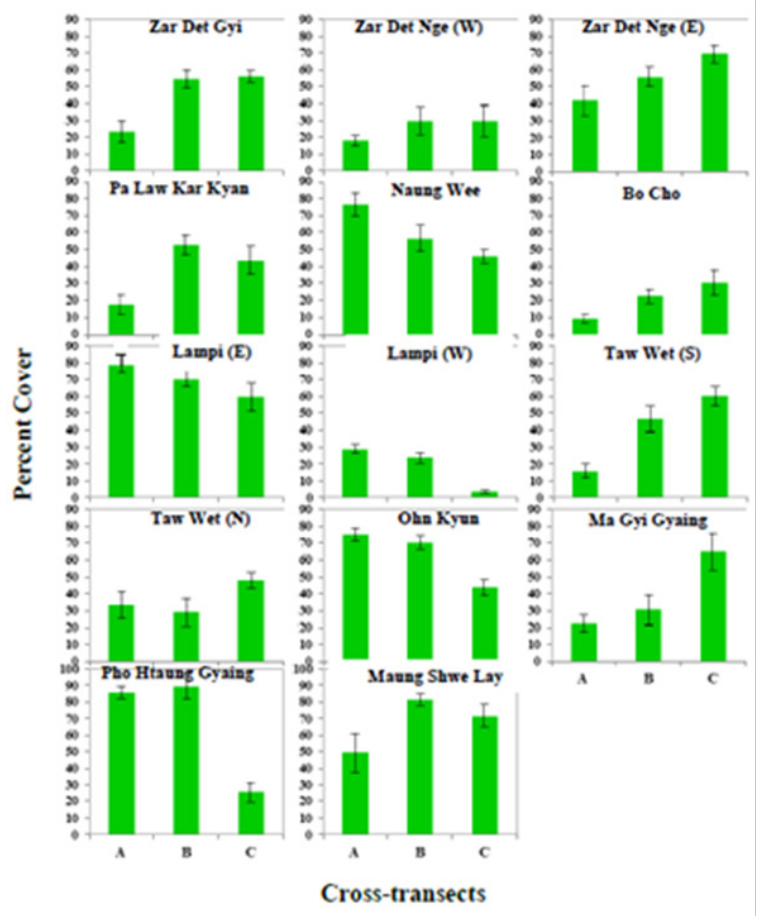

Figure 17 The percent cover of seagrasses along 3 cross-transects in 14 study sites. Abbreviations: A, B and C- Cross-transects.

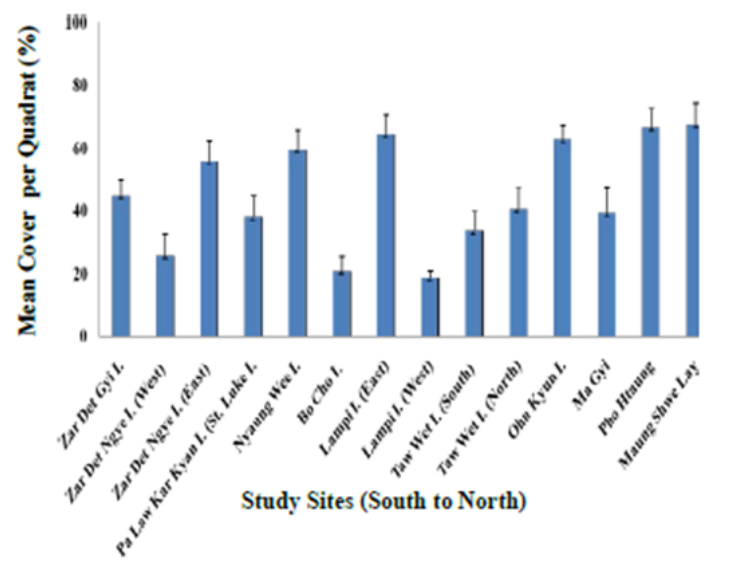

Figure 18 The mean percent cover of seagrasses along 3 cross-transects in 14 study sites (Mean seagrass cover per site $( \pm$ se).

\section{Discussion}

The current study was able to develop an easily replicable baseline for 14 seagrass sites within Myanmar to allow for long term monitoring of seagrass beds and provide the ability to quanitatively measure the impact of management interventions aimed at seagrass conservation. Of the 14 sites surveyed, only four had been previously studied using the same methodology, ${ }^{14}$ which were located in the Tanintahyi Region, and so comparisions can be made. Of the four only one, Lampi I. (East) showed an increase in percentage cover with $64.57 \%$ recorded in the current survey compared to $45 \%$ in the 2007 surveys. ${ }^{14}$ A number of reasons maybe responsible for this increase such as a decrease in shrimp and fish catch in the area leading trawlers to search 
elsewhere for catch or from the increase in presence of Department of Forestry staffs at Marine National Park headquarters in the Lampi Island opposite to the seagrass bed, resulting of greater support by the the NGO community to the MPAs management. Two of the other sites, Taw Wet I. (North) and Nyang Wee I., did show a decrease in percentage cover but only by $9 \%$ and $11 \%$ respectively, with such a result potentially down to transect placement. These sites will however need to be monitored to ensure that its only statistical errors causing this decrease and not anthropoengic impacts such as bottom trawling. The final site, which had previously been surveyed in 2007 , was Lampi I. (West) and this seagrass bed has seen an extensive loss in percentage cover with $18.75 \%$ recorded in this survey compared to $80 \%$ cover in 2007 . Boat activity in this area was observed to be quite high during the surveys with this part of Lampi Island providing protection for many boats during periods of high winds and as such could be targeted by trawlers when conditions away from the island are unfavourable. These seagrass beds were noted to have a high cover of sand sediments smothering their stems. The current support being provided to manage this Marine National Park by organisations such as the Italian NGO Oikos may help to ensure this seagrass beds protection and long term conservation.

Table 2 Coverage of seagrass beds in the Myeik Archipelago and Rakhine coastal areas

\begin{tabular}{|c|c|c|c|c|c|c|c|}
\hline & \multirow[b]{2}{*}{$\begin{array}{l}\text { Sr. } \\
\text { No. }\end{array}$} & \multirow[b]{2}{*}{ Locality (Date) } & \multirow[b]{2}{*}{ Position } & \multicolumn{4}{|c|}{ Cover (\%)/ Cross-transect } \\
\hline & & & & A & B & C & Total \\
\hline \multirow{10}{*}{ 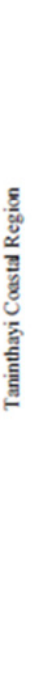 } & 1. & $\begin{array}{l}\text { Zax Det Gyi I. } \\
(23-3-15)\end{array}$ & $\begin{array}{l}\text { (Lat 10.02003, } \\
\text { Long 98.28963) }\end{array}$ & 23.33 & 54.58 & 56.25 & 44.72 \\
\hline & 2. & $\begin{array}{l}\text { Zar Det Ngye I. } \\
\text { (West) }(22-3-15)\end{array}$ & $\begin{array}{l}\text { (Lat 10.11687, } \\
\text { Long 98.28199) }\end{array}$ & 18.00 & 29.25 & 30.00 & 25.75 \\
\hline & 3. & $\begin{array}{l}\text { Zar Det Ngye I } \\
\text { (East) }(24-3-15)\end{array}$ & $\begin{array}{l}\text { (Lat 10.1251, } \\
\text { Long 98.3045) }\end{array}$ & 41.91 & 55.83 & 69.58 & 55.77 \\
\hline & 4. & $\begin{array}{l}\text { Pa Law Kax Kyan } \\
\text { I. (St. Luke I) } \\
\text { (21-3-15) }\end{array}$ & $\begin{array}{l}\text { (Lat 10.13461, } \\
\text { Long 98.21011) }\end{array}$ & 17.75 & 52.92 & 43.75 & 38.14 \\
\hline & 5. & $\begin{array}{l}\text { Naung Wee I. } \\
(20-3-15)\end{array}$ & $\begin{array}{l}\text { (Lat 10.50319, } \\
\text { Long 98.23227) }\end{array}$ & 76.25 & 56.67 & 46.25 & 59.72 \\
\hline & 6. & $\begin{array}{l}\text { Bo Cho I } \\
(18-3-15)\end{array}$ & $\begin{array}{l}\text { (Lat 10.66216, } \\
\text { Long 98.26) }\end{array}$ & 9.67 & 22.5 & 30.5 & 20.89 \\
\hline & 7. & $\begin{array}{l}\text { Lampi I (East) } \\
(19-3-15)\end{array}$ & $\begin{array}{l}\text { (Lat 10.70202, } \\
\text { Long 98.27948) }\end{array}$ & 78.3 & 70.83 & 44.58 & 64.57 \\
\hline & s. & $\begin{array}{l}\text { Lampi I (West) } \\
(16-3-15)\end{array}$ & $\begin{array}{l}\text { Lat } 10.88089^{\circ} \text {, } \\
\text { Long } 98.07436^{\circ} \text { ) }\end{array}$ & 28.83 & 23.75 & 3.68 & 18.75 \\
\hline & 9. & $\begin{array}{l}\text { Taw Wet I (South) } \\
(11-3-15)\end{array}$ & $\begin{array}{l}\text { (Lat } 11.37642^{\circ} \text {, } \\
\text { Long } 98.12234^{\circ} \text { ) }\end{array}$ & 29.17 & 24.17 & 47.91 & 33.75 \\
\hline & 10. & $\begin{array}{l}\text { Taw Wet I (North) } \\
(8-3-15)\end{array}$ & $\begin{array}{l}\text { (Lat } 11.40776^{\circ} \text {, } \\
\left.\text { Long } 98.12032^{\circ}\right)\end{array}$ & 15.83 & 45.67 & 60.00 & 40.5 \\
\hline & 11. & $\begin{array}{l}\text { Ohn Kyun I } \\
(8-5-15)\end{array}$ & $\begin{array}{l}\text { (Lat 16. 388785, } \\
\text { Long 94. 229125) }\end{array}$ & 75.00 & 70.25 & 43.75 & 63.00 \\
\hline$\stackrel{\vec{a}}{\underline{a}}$ & 12. & $\begin{array}{l}\mathrm{MaGyi} \\
(1-5-15)\end{array}$ & $\begin{array}{l}\text { (Lat 17.072122, } \\
\text { Long 94. 451406) }\end{array}$ & 22.50 & 30.67 & 64.83 & 39.33 \\
\hline 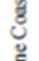 & 13. & $\begin{array}{l}\text { Pho Htaung } \\
(2-5-15)\end{array}$ & $\begin{array}{l}\text { (Lat 17.170547, } \\
\text { Long 94. 491739) }\end{array}$ & 85.67 & 89.17 & 25.42 & 66.75 \\
\hline 恶 & 14. & $\begin{array}{l}\text { Maung Shwe Lay } \\
(15-5-15)\end{array}$ & $\begin{array}{l}\text { (Lat 18. 305367, } \\
\text { Long 94. 329312) }\end{array}$ & 49.17 & $\$ 1.25$ & 71.67 & 67.36 \\
\hline
\end{tabular}

In the present study, however, unlike $\mathrm{Kress}^{20}$ no specimens of Zostrea marina were recorded. This species normally occurs in temperate waters and known to extend into the higher latitudes of Myanmar waters and has previously been found in all three Coastal Regions of Myanmar. Further surveys are therefore needed to eludciate the status of this species within the country.

Seagrass meadows were mostly in intertidal zone encountered in front of the mangrove communities in Tanintharyi whereas those in
Rakhine are commonly found in the subtidal zone in front of the sandy beaches (except for the seagrass meadow Pho Htaung Gyaing located behind the mangrove swamp). For this reason, the luxuriant growth of seagrasses was observed in all coastal areas of Rakhine due to moderate and favourable environmental parameters but not in coastal areas of the Myeik Archipelago of Tanintharyi Coastal Region due its natural habitat in the interdal zone under heavy environmental stresses (Table 3). In the present study, other uniquie species distributions include Halophila major which was solely found along the Rakhine coast $^{21}$ and $H$. ovalis which was exclusively encountered along the coastal areas of the Myeik Archipelago.

Table 3 The physical parameters of seagrass beds in 14 study sites

\begin{tabular}{|c|c|c|c|c|c|}
\hline \multirow{2}{*}{$\begin{array}{l}\text { Sr. } \\
\text { No. }\end{array}$} & \multirow[b]{2}{*}{ Study site } & \multirow{2}{*}{$\begin{array}{c}\text { Area of } \\
\text { seagrass } \\
\text { meadow } \\
\text { (ac) }\end{array}$} & \multicolumn{3}{|c|}{ Physical parameters } \\
\hline & & & $\begin{array}{l}\text { Temp } \\
\left({ }^{\circ} \mathrm{C}\right)\end{array}$ & Salinty (\%o) & $\begin{array}{l}\text { Depth } \\
\text { (m) }\end{array}$ \\
\hline & $\begin{array}{l}\text { Taninthayi Coastal } \\
\text { Region: }\end{array}$ & & & & \\
\hline 1. & Zar Det Gyi I. & 32.80 & 33 & 32 & 0 \\
\hline 2. & Zar Det Ngye I (West) & 12.10 & 29 & 32 & 0 \\
\hline 3. & Zar Det Ngye I (East) & 19.90 & 33 & 32 & 0 \\
\hline 4. & $\begin{array}{l}\text { Pa Law Kar Kyan I. } \\
\text { (St. Luke I.) }\end{array}$ & 83.00 & 28 & 32 & 0 \\
\hline 5. & Nyaung Wee I. & 46.40 & 33 & 32 & 0 \\
\hline 6. & Bo Cho I. & 382.50 & 30 & 32 & 0 \\
\hline 7. & Lampi I (East) & 216.70 & 30 & 32 & 0 \\
\hline 8. & Lampi I. (West) & 10.60 & 29 & 32 & 0 \\
\hline 9. & Taw Wet I (South) & 28.90 & 30 & 35 & 0 \\
\hline \multirow[t]{2}{*}{10.} & Taw Wet I (North) & 45.50 & 32 & 32 & 0 \\
\hline & Rakhine Coastal Region: & & & & \\
\hline 11. & Ohn Kyun I. & 17.30 & 29 & 32 & 5 \\
\hline 12. & Ma Gyi Gyaing & 39.83 & 28 & 32 & 3 \\
\hline 13. & Pho Htaung Gyaing & 94.22 & 29 & 32 & 3 \\
\hline 14. & Maung Shwe Lay Gyaing & 23.79 & 28 & 32 & 3 \\
\hline
\end{tabular}

Table 4 Seagrass sites ranked according to uniqueness, species richness and percentage cover with I being the highest priority for protection and 5 the least. Shaded boxes indicate priority sites

\begin{tabular}{|c|c|c|c|c|c|c|}
\hline $\begin{array}{l}\text { Sr. } \\
\text { No. }\end{array}$ & Site & Uniquness & $\begin{array}{l}\text { Species } \\
\text { richness }\end{array}$ & $\begin{array}{c}\% \\
\text { Cover }\end{array}$ & $\begin{array}{l}\text { Cumulative } \\
\text { score }\end{array}$ & Rank \\
\hline 1. & Zar Det Gyi I. & 9 & 3 & 2 & 14 & 5 \\
\hline 2. & $\begin{array}{l}\text { Zar Det Ngye I } \\
\text { (West) }\end{array}$ & 9 & 3 & 3 & 15 & 5 \\
\hline 3. & $\begin{array}{l}\text { Zar Det Ngye I. } \\
\text { (East) }\end{array}$ & 3 & 2 & 1 & 6 & 3 \\
\hline 4. & $\begin{array}{l}\text { Pa Law Kar } \\
\text { Kyan I. }\end{array}$ & 3 & 2 & 2 & 7 & 4 \\
\hline 5. & Nyaung Wee I. & 9 & 3 & 1 & 13 & 5 \\
\hline 6. & Bo Cho I & 9 & 3 & 3 & 15 & 5 \\
\hline 7. & Lampi I (East) & 9 & 4 & 1 & 14 & 5 \\
\hline 8. & Lampi I (West) & 10 & 5 & 3 & 18 & 5 \\
\hline 9. & $\begin{array}{l}\text { Taw Wet I } \\
\text { (South) }\end{array}$ & 9 & 5 & 2 & 16 & 5 \\
\hline 10. & $\begin{array}{l}\text { Taw Wet I } \\
\text { (North) }\end{array}$ & 9 & 4 & 2 & 15 & 5 \\
\hline 11. & Ohn Kyun I. & 3 & 3 & 1 & 7 & 4 \\
\hline 12. & Ma Gyi Gyaing & 1 & 1 & 2 & 4 & 1 \\
\hline 13. & $\begin{array}{l}\text { Pho Htaung } \\
\text { Gyaing }\end{array}$ & 3 & 1 & 1 & 5 & 2 \\
\hline 14. & $\begin{array}{l}\text { Maung Shwe } \\
\text { Lay Gyaing }\end{array}$ & 3 & 3 & 1 & 7 & 4 \\
\hline
\end{tabular}


Although Soe-Htun et al. ${ }^{12}$ reported there were no stresses in the meadows of seagrasses in coastal areas of Myanmar, with these ecosystems showing pristine and climax conditions; they are now facing the problems such as smothering by sand as noted above. Such issues can arise from trawlers stirring up sediments or from landslides where forest areas have been cleared such as those observed on Zar Det Gyi I. In general, seagrass beds in Myanmar are exposed to a number of threats including runoff from cities and towns and hazardous wastes and oil dispersals released from industrial zones located in the upper areas of natural seagrass beds are seen as serious threats to these habitats. Bottom trawlers also operate directly through seagrass beds targeting shrimps and other marine species destroying these habiats. Smoothering of seagrasses in sediments from sand mining operations in the Myeik Archipelago resulting in reduced ability of seagrasses to photosynthesize.

Management actions are therefore required immediately to ensure these habitats are not lost which would have deveastaing consequences for both the aquatic environement and for people's livelihoods. However given the limited resources available in Myanmar to manage all these areas focus must be steered towards those sites which could be considered key biodiverse areas. Therefore, to prioritise the most important sites and focus management inteverntions a simple ranking system was developed for the surveyd areas using uniqueness (in terms of species representation), species richness and percentage seagrass cover (Tables 1-4). Although all sites should receive some level of protection six sites stood out in terms of the above paramters with Ma Gyi Gyaing (39.83 ac) in Rakhine consider the most important site being 1 ) one of the most diverse, 2) the only site to conatin Halophila beccarii, the most threatened of all the 12 species recorded with a ranking of Vulnerable under the IUCN Redlist, and 3 ) because of its high percentage cover. Moreover, in terms of species diversity of seagrasses, Ma Gyi and Pho Htaung Gyaings showed the highest in the Rakhine Coastal Region with 9 species while Zar Det Ngye (East) I. and Pa Law Kar Kyan I, represented higest in the Myeik Archipelago waters including 7 species of seagrasses (Tables 1). Highest percentage cover of seagrass meadows was observed at Maung Shwe Lay Gyaing, in Rakhine Coastal Region with 67.36\% whereas the lowest was at Lampi I. (West) with $18.75 \%$ (Tables 2), (Figures 17-18). Other sites worthy of immediate protection include Pho Htaung Gyaing (94.22 ac), Zar Det Ngye I. (East)(19.90 ac), Pa Law Kar Kyan I. (St. Luke I.)(83.00 ac), Ohn Kyun I. (17.30 ac) and Maung Shwe Lay Gyaing (23.79 ac) (Tables 3). As a first step, these sites should be provided some level of protection either as strict notake MPAs or has carefully managed gear restricted areas with a strong emphasis on bottoms trawlers and other gears with may negatively impact the seagrass.

Such processes can however take time and require human capacity and various other resources to manage such interventions. As such a number of required actions have been recommended which are seen as necessary for effective management of seagrasses in Myanmar and designed to guide decision makers in developing conservation plans for seagrasses to ensure these habitats are protected as follows:

1. Designation of key seagrass areas as marine protected areas (MPAs) linked with wider spatial planning exercises for the two main coastal areas with seagrass beds notably Taninthayi and Rakhine Coastal Regions.

2. Encourage international support and form partnerships with regional bodies for the conservation of seagrass ecosystems.

3. Share the results of local and regional research on seagrass ecosystem functions and values, and establish national and regional ecological networks and corridors for the management of seagrass ecosystems.

4. Provide financial and technical support to various Myanmar institutions such as government departments and universities, including capacity-building for community-based biodiversity conservation efforts.

5. Improve public knowledge and recognition of the importance of seagrass habitats through nationwide education and awareness programmes targeting policy and decision makers, fishers and local communities and those involved in activities which impact seagrass beds.

6. Strengthen national, regional and international efforts to ensure invasive alien species are controlled, which could cause great biodiversity loss in seagrass communities. This should include the development of an effective work programme on invasive alien species.

7. Intensify water pollution prevention for industrial hazardous wastes from the special economic zone and regularly examine the water quality standards for costal and marine areas by establishing monitoring systems and effective legal frameworks for conservation of seagrass meadows.

8. Ensure seagrass conservation is included in any coastal development projects and in all regional/state development plans.

9. Undertake further detailed research on seagrass habitats including surveys of the ecosystem services provided by seagrass beds with a special focus on their importance to fisheries;

10. Regularly monitor the status of seagrass ecosystems along the coast of Myanmar including on ground surveys and satellite remote sensing analysis.

11. Identify the potential impacts on seagrasses from climate which may cause these habitats to degrade leading to food security issues for local communities.

\section{Conclusions}

A total of 14 study sites- ten study sites, viz., Zar Det Gyi I, Zar Det Ngye I (West), Zar Det Ngye I (East), Pa Law Kar Kyan I (St. Luke I), Naung Wee I, Bo Cho I, Lampi I (East), Lampi I. (West), Taw Wet I (South) and Taw Wet I (North) in the Myeik Archipelago of the Taninthayi Coastal Region and four study sites, namely Ohn Kyun I., Ma Gyi Gyaing, Pho Htaung Gyaing and Maung Shwe Lay Gyaing in the Rakhine Coastal Region, were surveyed to assess the current status of seagrasses growing along the coastal areas of Myanmar. Eleven species of seagrasses were recorded from the Myeik Archipelago and Rakhine coastal areas of Myanmar, including Syringodium isoetifolium, Cymodocea rotundata, C. serrulata, Halodule uninervis, H. pinifolia, Enhalus acoroides, Thalassia hemprichii, Halophila beccarii, H. decipiens, $H$. ovalisand $H$. major. Taxonomic key to the species of seagrasses collected from the two study areas in Myanmar:

Of the 11 species of seagrasses collected in this study, only one, Halophila beccarii is considered Vulnerable according to the IUCN RedList, with all other species listed as Least Concern. Halophila beccarii was only recorded at Ma Gyi Gyaing. Of these species, Halodule pinifolia was the most commonly observed species. Ma Gyi Gyaing, being the only site to conatin the Vulnerable listed Halophila beccarii species and beacsue of its high percent cover, should be gazzetted as a Marine Protected Area (MPA) along 
with Pho Htaung Gyaing, and Zar Det Ngye (East) given their species diversity and extent.

\section{Acknowledgments}

The first author, U. Soe-Htun is very grateful to the late Dr. U. Min-Thein, Director (Retd), Microalga Biotechnology Department, Myanmar Phamaceutical Factory (MPF), Yangon, Myanmar for invaluable guidance in the studies of seagrasses since his surveys in Maung Shwe Lay Gyaing in 1980. We are indebted to Robert Howard, FFI Myanmar's Marine Conservation Programme Manager, for his useful assistance during this study. We would like to express our sincere thanks to the local people who kindly help us in many ways during our field trips. Many thanks go to U Thaung Htut and U Zaw Lin Tun, Staffs of Marine Science Association, Myanmar (MSAM) for their helpful assistance in the preparation of the manuscript. Funding for this work from the the Bay of Bengal Large Marine Ecosystem (BOBLME) Project "Seagrass Monitoring in Myanmar", under a joint project with Fauna \& Flora International and BOBLME of the Food and Agriculture Organisation (FAO) of the United Nations, is most appreciated.

\section{Conflicts of interest}

None.

\section{References}

1. Green EP, Short FT. World atlas of seagrasses. UIMEP World Conservation Monitoring Centre. University of California Press, Berkeley, USA. 2003;pp.332.

2. Short FT, Carruthers T, Dennison W, et al. Global seagrass distribution and diversity: A bioregional model. Journal of Experimental Marine Biology and Ecology. 2007;350(1-2):3-20.

3. Dawes CJ. Marine botany. Wiley. Interscience. 1981;pp.629.

4. Zieman JC, Zieman RT. The ecology of the seagrass meadows of the west coast of Florida: A community profile. US Fish Wild Serv Biol Rep. 1989;85(7.25):155.

5. Dawes CJ, Phillips RC, Morrison G. Seagrass communities of the Gulf Coast of Florida: Status and ecology. Florida fish and wildlife conservation commission fish and wildlife research institute and the Tampa Bay estuary program. St. Petersburg. 2004;pp.74.

6. Adulyanukosol K, Poovachiranon S. Dugong (Dugong dugon) and seagrass in Thailand: present status and future challenges. In: Arai $\mathrm{N}$ (Eds.), Proc 3rd Int. Symp. SEASTAR and Asian Bio-logging Science. 2006;pp.41-50.

7. Nakanishi $\mathrm{Y}$, Hosoya $\mathrm{S}$, Arai $\mathrm{N}$, et al. The distribution of seagrass meadows and dugong feeding trails in the dry season around Talibong Island, Trang Province, Thailand. In: Arai N. (Ed.), Proc 3rd Int. Symp. SEASTAR2000 and Asian Bio-logging Science. 2006;pp.55-62.
8. Orth RJ, Carruthers T, Denisson JB, et al. A global crisis for seagrass ecosystems. BioScience. 2006;56(12):987-996.

9. Den Hartog C. The sea-grasses of the world. North-Holland Publishing Company. Amsterdam. 1970;275.pp.

10. Min-Thein U, Aung-Myint U, Kyi-Shwe U. A list of some noteworthy species of marine algae and Angiosperms from the Andrew Bay, Burma. Proceedings of the Burma Research Congress. 1979;pp.10-17.

11. Soe-Htun U, San-Tha-Htun U, Aye-Mon-Sein, et al. A summary reports on the seaweeds and seagrasses of the Myeik (Mergui) Archipelago. Tech. Rep. 1997;pp.7.

12. Soe-Htun U, San-Tha-Htun U, Mu Mu Aye, et al. Notes on seagrasses along Myanmar Coastal Regions. Bull Mar Sci Fish Kochi Univ No. 2001;20:13-22.

13. Soe-Htun U, Mya Kyawt Wai, Thida Nyunt, et al. Seagrass of Myanmar with special reference to the phytogeographic distribution of the species of ASEAN nations. Journal of Myanmar Academy of Art and Science. 2009; 7(5):263-387.

14. Novak AB, Hines E, Kwan D, et al. Revised ranges of seagrass species in the Myeik Archipelago, Myanmar. Aquatic Botany. 2009;91(3):250252

15. Tint Tun, Barry B. Preliminary observation on the seagrasses of Lampi and neighbouring islands of the Myeik Archipelago, Myanmar. Proceedings of the 6th International Symposium on SEASTAR2000 and Asian Bio-logging Science (The 10th SEASTAR workshop) Thailand. 2011;pp.85-91.

16. Kuo J, Kanamoto Z, Iizumi H, et al. Seagrasses of the genus Halophila Thouars (Hydrocharitaceae) from Japan. Acta Phytotax. Geobot. 2006;57(2):129-154.

17. Fortes MD. Seagrasses: Their role in marine ranching. In: Ohno M \& Critchley AT (Eds.), Seaweed cultivation and marine ranching. Kanagawa International Fisheries Training Center Japan. International Cooperation Agency (JICA). 1993;pp.131-151.

18. Short FT, Coles R. Global seagrass research methods. Elsevier Science, Amsterdam. 2001;pp.506.

19. Short FT, McKenzie LJ, Coles RG, et al. SeagrassNet manual for scientific monitoring of seagrass habitat. Worldwide Edition. University of New Hampshire Publication. 2006;75.pp.

20. Kress WJ, Defilipps RA, Yin Yin Kyi. A checklist of the trees, shrubs, herbs, and climbers of the Myanmar. Contributions from the United States National Herbarium. 2003;45:1-590.

21. Nguyen XV, Detcharoen M, Tuntiprapas P, et al. Genetic species identification and population structure of Halophila (Hydrocharitaceae) from the Western Pacific to the Eastern Indian Ocean. BMC Evol Biol. 2014;14(92):1471-2148 